\title{
Panel Analysis of Telephony Mobile Albania
}

\author{
Prof.As.Dr. Valentina Sinaj
}

Economics Faculty, Tirana Albania, sinajv@yahoo.com

\section{Serena Leka}

Economics Faculty, Tirana Albania, serena_leka@hotmail.com

\author{
Doi:10.5901/ajis.2014.v3n2p365
}

\begin{abstract}
Telecommunications has been one of the most dynamic service activities in Albania, being developed under privatization and investments of foreigners and locals investments. The mobile phone market has experienced significant growth thanks to increased competition in the market at the moment that AMC has joined Vodafone and Eagle Mobile afterwards, followed by the company PLUS. Specifically, mobile companies are at the top of the list in terms of revenue collection. The telecommunications market in Bangladesh has room for further growth given that he is under the maturity level compared to European countries. Fixed line sector in this market marks the lowest rate of his penetration, about $11 \%$. His appearance with a poor infrastructure encourages customers to use mobile mass, ranking Albania in one of the countries with the highest mobile penetration in Europe. The paper considers the period 2008 - 2012, during which the mobile market is composed of only three companies: Vodafone, AMC and Eagle Mobile. So the paper observed three companies, each for a period of five years. For such a work can be built upon an analysis of panel data.
\end{abstract}

Keywords: Casuality, random effect, cross-section.

\section{Introduction}

Nowadays, individuals and businesses have the need to be "connected" and the telecommunications infrastructure facilitates a better and faster communication. This necessity is the driving force in the change of how people do business and socially interact in everyday life. The telecommunications industry is considered the engine of every global economy. The cellphone has become the leading tool of communication in Albania. According to the latest polls 1 out of 2 Albanians is a cellphone user.

The developement of cellphone companies and the enrichment of the services they offer is directly connected with the developement of their mobile network. In the last decades the mobile technology has gone through a change of 4-5 different generations,appropriately named $O G$ to $4 G$. In order to take full advantage of the plethora of services offered through the mobile networks, a compatible device is needed to take full advantage of the multitude of the applications offered in different applied markets. So,in the later years, the market of compatible and able devices has changed drastically.

In Albania, the mobile market is an oligopolistic market divided into four major providers, Vodafone, AMC, Eagle Mobile andPlusCommunication,that provide the same services in this market. The industry being dominated by a small number of big companies where each one owns a big slice of the pie are the fundamental traits of this market. This phenomenon makes these companies very powerful in their own way.It is not a monopoly, but they have a firmer grasp on the industry than in a free market.

\section{The Growth of Mobile Communications in Albania}

The development of postal \& telecommunications in Albania has been dictated by the need to be connected in greater and greater distances as a consequence of an economical, cultural and social growth. The first steps were taken by the government established by Ismail Qemali, who founded the Ministry of Postal-Telegraph \& Telephone Communications.

Later on, in the year 1921, in Tirana was installed the first manual telephone exchange containing 200 numbers. Some time passed before the postal \& telephone services became separated. This happened in 1992, when "TelekomiShqiptar" was founded, as a governmental run subsidy offering services in landline communications. 
It was not until the year 1996 when for the first time mobile communication services were offered by AMC. This service, until 1999, was available only in the area Tirana -Durres,in the Western Lowlands, covering around 15.000 subscribers.

In August of 2001, the second provider, Vodafone Albania, was licensed. In July of 2002 the number of subscribers reached 700.000 . The area covered reached $65 \%$ of the country and $85 \%$ of the population.

In March of 2004, ALB Telecom procures the third license for Eagle Mobile but it doesn't start operations until March 2008. By the end of the same year the number of subscribers reaches 2.7 million or $85 \%$ of the county's population.

In November of 2010 the fourth provider of mobile services, "Plus Communications", enters the market. In doing so, establishing better premises for a more efficient market competition.

\subsection{Short description of mobile companies.}

a) AMC (Albanian Mobile Communication JSC) is the first Albanian company providing mobile communication services. It was founded in 1996 as a government investment with a starting capital of $\$ 8$ million, of which, $\$ 7$ millionwas a loan taken from the Savings Bank of Albania.

The company had 20.000 subscribers until the year 1999. In May of 2000 ,the Albanian government, through an open international tender sold $85 \%$ of the company to the winning bidder being the Greek company Cosmote. As a result of new investments and products the company enjoyed a titanic growth in the years to follow, surpassing 1 million subscribers in 2006.

Today, AMC finds itself as the undisputed leader of mobile communications in Albania. In May 2010 this company celebrated their 2 million subscriber, a record number in the Albanian market. AMC has brought to market a diversity of plans and packets, Prepaid \& Postpaid.Their entry plans "Alba Karta What's Up" \& "AMC Karta" are very convenient and can be found everywhere.

AMC holds another record in the Albanian market. As a leader in the industry, this company was the first to offer Wireless Data which were welcomed with booming sales by the Albanian subscribers. AMC offers $3 G$ speed data connection nationwide. In 2009, likewise the Greek companies OTE and Cosmote, AMC was acquired by the German giant telecommunication T-Mobile. In September 2011, in a national tender, AMC won the rights to the second license available nationwide for providing $3 G$ services. AMC holds the fastest $3 G$ network in Albania.

b) Vodafone Albania JSCis part of the Vodafone Group Plc, a worldwide leader in the electronic communications industry. The Vodafone brand is ranked as the seventh most valuable brand in the world. Vodafone is present in over 30 different countries and partners with other mobile providers in over 40 countries. Vodafone entered the Albanian market in August of 2001 through a blazing fast process of building and operating a mobile network thanks to the extended experience with mobile networks worldwide.

Vodafone Albania is the first mobile provider in Albania to introduce the public to $3 G$ technology in January 2011.Currently, Vodafone covers over 99\% of the population with 3G signal. Vodafone offers its 1.8 million subscribers in Albania a wide range of high quality services, including voice and data, providing the best mobile network and innovative offers. Vodafone Albania owns an extended network of 136 shops nationwide,open 7 days a week. These shops provide products and services offered by Vodafone, as well as mobile phones, accessories and technical assistance. Vodafone Albania is one of the biggest companies in Albania, giving a significant contribution to the Albanian economy.

c) Eagle Mobile is the third provider of mobile communications to enter the Albanian market.By signing the privatization contract between the Albanian government and a Turkish conglomerate composed of Çalik Group \& Turkish Telecom the Albanian consumer benefited a third mobile provider. Eagle Mobile is part of ALB Telecom, the biggest provider of telecommunications in Albania. Eagle Mobile offers services in mobile voice and to broadband data 3G in Albania. The merger between the mobile company and ALB Telecom started in March 2011 and was finalized on February the 1st 2013. Prior to this merger this companies operated as separate entities.Now,it's easier for the consumer to access all the services they need mobile or broadband, under the same roof. This is common practice in the developed world, where the differences between landlines \& mobile have become to blur. EM has a nationwide coverage of broadband \& mobile network of $92.5 \%$, also its signal reaches $98.5 \%$ of the population.EM has an estimated 1.472 .000 subscribers. It offers international Roaming in over 220 countries and over 420 providers. Its network of shops is fused with ALB 
Telecom and it's estimated at 150 . This company provides the latest $3 G$ technology and offers the fastest broadband in Albania using Dual-Carrier HSDPA+ technology,clocked in at 40Mbps in various tests, a pinnacle speed for $3 G$ in Albania.

\section{Methodology}

In studying the mobile market in Albania, the method of analyzing a data panel is used. The data concerning the revenue of the aforementioned companies during the period of 2008-2012 is been possible from the Authority of Electronic \& Postal Communications and the Cullen International. In this study,only 3 (Vodafone, AMC \& Eagle Mobile) out of the 4 mobile communications companies are included. The fourth company,Plus Communication, it's not included due to the fact that it entered the market relatively late, in the year 2010. So,to keep a balanced approach,was seen reasonable to use only the 3 in the study.

\subsection{Factors Included in the model}

This model represents a detailed analysis of the mobile communications market. The variables included are the revenues \& subscribers of each company for the period of 2003-2012. The companies shown are Vodafone \& AMC, also Eagle Mobile for the period of 2008-2012

Revenue...is income that an individual or company receives in exchange of providing goods or services,or from the investment of capital.In business, revenue implies total revenue minus total expenses and taxes in a given period. In this case, it is also known as Profit. In our case, the revenue is yearly and shows the income that the company receives from its normal business activities. The income comes from the sales of SIM cards for new subscribers,refilling old cards,call fees,SMS fees, etc.

Subscribers...include every consumer using the goods and services offered from these companies. This is the second variable in the study. It is included because it is proportionally linked with the revenue of the companies. The bigger the number the bigger the revenue and vice-versa.

Below,the revenue for each mobile company is shown for the years 2003-2012,also, the number of subscribers for the same years.

Table 1. Revenue for each company

\begin{tabular}{|l|c|c|c|c|c|c|c|c|c|c|}
\hline Year & $\mathbf{2 0 0 3}$ & $\mathbf{2 0 0 4}$ & $\mathbf{2 0 0 5}$ & $\mathbf{2 0 0 6}$ & $\mathbf{2 0 0 7}$ & $\mathbf{2 0 0 8}$ & $\mathbf{2 0 0 9}$ & $\mathbf{2 0 1 0}$ & $\mathbf{2 0 1 1}$ & $\mathbf{2 0 1 2}$ \\
\hline Vodafone & 13266 & 17007 & 19605 & 21483 & 23075 & 24919 & 22877 & 20165 & 20347 & 23520 \\
\hline Eagle & & & & & & 600 & 4362 & 5166 & 4865 & 4342 \\
\hline AMC & 15526 & 17106 & 18326 & 19811 & 21785 & 23471 & 19975 & 16552 & 13214 & 12315 \\
\hline
\end{tabular}

Source: AKEP

Figure 1. Trend of Revenue for each company

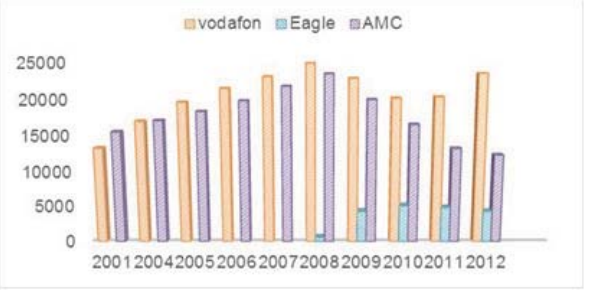

Source: AKEP(author's thoughts)

As we can notice in the graph, AMC has higher levels of revenue in the early years, whereasin the following years is Vodafone that has higher levels of revenue. In the year 2012, Vodafone has almost double the revenue of AMC. EM has a considerable increase of revenue in 2009 , but following that its revenue has stalled in similar levels. 
Table 2. Subscribers for each company

\begin{tabular}{|l|c|c|c|c|c|c|c|c|c|c|}
\hline Year & $\mathbf{2 0 0 3}$ & $\mathbf{2 0 0 4}$ & $\mathbf{2 0 0 5}$ & $\mathbf{2 0 0 6}$ & $\mathbf{2 0 0 7}$ & $\mathbf{2 0 0 8}$ & $\mathbf{2 0 0 9}$ & $\mathbf{2 0 1 0}$ & $\mathbf{2 0 1 1}$ & $\mathbf{2 0 1 2}$ \\
\hline Vodafone & 506807 & 620467 & 748748 & 919606 & 1127253 & 1310723 & 1674741 & 1674748 & 1809264 & 2019625 \\
\hline Eagle & & & & & & 257761 & 601117 & 822356 & 1110363 & 1423421 \\
\hline AMC & 592804 & 638728 & 781496 & 990279 & 1195183 & 1395989 & 1908972 & 2022541 & 1920000 & 1874221 \\
\hline
\end{tabular}

Source: AKEP

Figure 2. Trend of Subscribers for each company

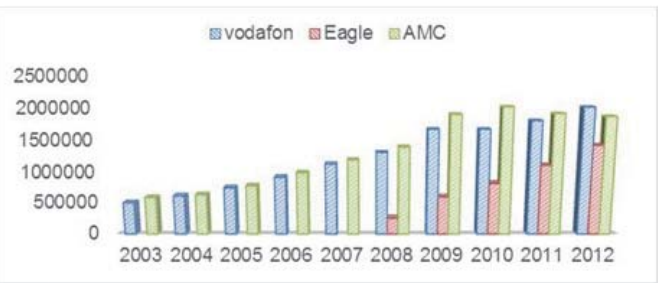

Source: AKEP(author's thoughts)

When it comes to the number of subscribers, it is seen that both companies follow the same trend, followed with an better increase in numbers for AMC in the years 2009 and 2010, a period this,coinciding with AMC offering the "What's Up" packet. Also notable is the fast market growth of Eagle Mobile.

\subsection{Granger's Test of Casuality}

The first attempt to test causality was proposed by Granger(1969).The Granger causality test is a statistical hypothesis test for determining whether one time series is useful in forecasting one or more other ones.A time series $X$ is said to Granger-cause $Y$ if it can be shown, usually through a series of t-tests and F-tests on lagged values of $X$ (and with lagged values of $Y$ also included), that those $X$ values provide statistically significant information about future values of $Y$.Results of this test are shown below:

Table 3. Results of the Granger's Test ( Author's Work )

\begin{tabular}{lccc}
\hline \hline Null Hypothesis: & Obs & F-Statistic & Prob. \\
\hline \hline PR does not Granger Cause TR & 22 & 14.2396 & 0.0013 \\
TR does not Granger Cause PR & & 0.07418 & 0.7883 \\
\hline \hline
\end{tabular}

In the first hypothesis is seen that the statistical Fisher value is 14.2, a value this greater than the critical value showing that the hypothesis is not true.So,we can say that the increase in subscribers causes an increase in revenue for the mobile companies. The other hypothesis, on the other hand,is false.On the second row in the above table the value of Fisher is 0.07 , smaller than the critical value. We can say that the causality link between the two variables is unilateral.

\subsection{Econometric Model}

The usual model for mobile companies is of the form Log-Log as is shown in the model below:

$\log ($ revenue $)=F(\log ($ number of subscribers) $)$

Since the data is collected in graph form we can build models with set outcomes or models with variable outcomes based on the companies or time periods.From the research, the best model for the Albanian companies is the one with set outcome regardless of the company or time period.This conclusion was reached based on the Hausman test,which is used to select between models with set outcomes and those with variable outcomes.

The overall model is:

$\log ($ revenue $)=\beta_{0}+\log ($ nr of subscribers $)+\sum_{i=1}^{2} \alpha_{i}$ companies $_{i}+\sum_{i=0}^{8} \gamma_{i}$ Year $\quad 2003+i+u_{i t}$ Where the variable: the company is a quality variable that takes the value 1 if is linked to $i$-s company and takes 
the value 0 if otherwise.

The year: $2003+i$ is a quality variable that takes the value 1 if it's linked to the relevant year and takes the value 0 if otherwise.

The evaluated model in our case is:

Table 4.The model with set outcomes(Author's Work)

\begin{tabular}{|c|c|c|c|c|c|c|}
\hline \multicolumn{5}{|c|}{$\begin{array}{l}\text { ependent Variable: } L O G(T R) \\
\text { Method: Panel Least Squares } \\
\text { Date: } 04 / 01 / 14 \text { Time: } 23: 55 \\
\text { Sample: } 20032012 \\
\text { Periods included: } 10 \\
\text { Cross-sections included: } 3 \\
\text { Total panel (unbalanced) observations: } 25 \\
\text { White cross-section standard errors \& covariance (no d.f. } \\
\text { correction) } \\
\text { WARNING. estimated coefficient covariance ma trix is of reduced } \\
\text { rank }\end{array}$} & \multirow{3}{*}{$\begin{array}{c}\text { Kompanite } \\
\text { Vodafon } \\
\text { AlM } \\
\text { Eagle }\end{array}$} & \multirow{3}{*}{$\begin{array}{c}\text { Effect } \\
0.238542 \\
-0.039855 \\
-0.198687\end{array}$} \\
\hline Variable & Coefficient & Std. Error & t-S tatistic & Prob. & & \\
\hline \multirow[t]{2}{*}{$\begin{array}{c}C \\
L O G(P R)\end{array}$} & $\begin{array}{r}-14.69812 \\
1.742719\end{array}$ & $\begin{array}{l}6.038741 \\
0.435208\end{array}$ & $\begin{array}{r}-2.433971 \\
4.004340\end{array}$ & $\begin{array}{l}0.0315 \\
0.0017\end{array}$ & & \\
\hline & \multicolumn{4}{|c|}{ Effects Specification } & DATE & \\
\hline \multicolumn{5}{|c|}{$\begin{array}{l}\text { Cross-section fixed (dummy variables) } \\
\text { Period fixed (dummy variables) }\end{array}$} & $\begin{array}{l}1 / 1 / 2003 \\
1 / 1 / 2004\end{array}$ & $\begin{array}{l}1.141667 \\
1.073005 \\
0.838995\end{array}$ \\
\hline $\begin{array}{l}\text { R-squared } \\
\text { Adjusted R-squared } \\
\text { S.E. of regression } \\
\text { Sum squared resid } \\
\text { Log likelihood } \\
\text { F-statistic } \\
\text { Prob(F-statistic) }\end{array}$ & $\begin{array}{l}0.948291 \\
0.896582 \\
0.272599 \\
0.891725 \\
6.194953 \\
18.33904 \\
0.000007 \\
\end{array}$ & $\begin{array}{l}\text { Mkan depe } \\
\text { S.D. depen } \\
\text { Akaike inf } \\
\text { Schwarz CE } \\
\text { Hannan-Q } \\
\text { Durbin-W }\end{array}$ & $\begin{array}{l}\text { ndent var } \\
\text { dent var } \\
\text { ecriterion } \\
\text { iterion } \\
\text { inn criter. } \\
\text { tson stat }\end{array}$ & $\begin{array}{l}9.483047 \\
0.847671 \\
0.544404 \\
1.178219 \\
0.720197 \\
1.538936\end{array}$ & $\begin{array}{l}1 / 1 / 2006 \\
1 / 1 / 2007 \\
1 / 1 / 2008 \\
1 / 1 / 2009 \\
1 / 1 / 2010 \\
1 / 1 / 2011 \\
1 / 1 / 2012\end{array}$ & $\begin{array}{l}0.538273 \\
0.280231 \\
-0.080576 \\
-0.317641 \\
-0.581591 \\
-0.862766 \\
-1.070017\end{array}$ \\
\hline
\end{tabular}

Based on the results we can state that a $1 \%$ increase in the subscriber numbers sets a $1.7 \%$ in revenue.More so,89\% of the variation in revenue of the companies in the studyis directly linked to the number of subscribers that company has.

Evaluating the effects in the cross-section,we can see that Vodafone has been better positioned than the other two companies in the study,AMC \& Eagle Mobile. This is as a result of the bigger share of the market that the company has, its robust marketing,a great performance through the years etc. We can also note that AMC,regardless of the considerable share of the market(the second after Vodafone) has a lower level of revenue.This,according to AKEP, is a result of many AMC numbers being non-active.This fact makes for that part of the market to be "blown" out of proportion.Also, it is seen that Eagle Mobile has had a great performance,regardless of coming late to the party.

\section{Conclusions}

The data graph gives us the chance to study the possible existence of a link between revenue and the number of subscribers in the companies in the mobile industry.Granger's test supports the model ideated at the beginning of our work, stating the existence of unilateral causality link....the more the subscriber number grows, the bigger the revenue. In our analysis, the Hausman test results clearly show that the best model,time period based or cross-sectional based, is the model with set results.Also,based on this study, we come to the conclusion that the revenue is lightly affected by the level of fees, but drastically affected by market share.This, is shown by the market itself.The mobile industry is a form of oligopoly, where prices \& fees differ slight or none from carrier to carrier.

\section{Reference}

AKEP (2011).Raportivjetor 2010. Retrieved from http://www.akep.al/images/stories/AKEP/publikime/raporte/Raporti-Shqip-10-10-11.pdf, AKEP (2013). Raportmbiveprimtarinë e AKEP përvitin 2012.Retrieved from http://www.akep.al/images/stories/AKEP /publikime/2013/raporti-vjetor-2012.pdf,

Cullen International. (2012). Supply of services in monitoring regulatory and market developments for economic communications and information society services in Enlargement Countries(2nded.). Retrieved from http://www.cullen-international.com/events /research/studies/2013/04/monitoring-of-electronic-communications-in-the-enlargement-countries-3/monitoring-of-electroniccommunications-in-the-enlargement-countries-3

Cullen International. (2013). Supply of services in monitoring regulatory and market developments for economic communications and information society services in Enlargement Countries (3nded.). Retrieved from http://www.cullen-international.com/events /research/studies/2013/04/monitoring-of-electronic-communications-in-the-enlargement-countries-3/monitoring-of-electroniccommunications-in-the-enlargement-countries-3 
